ROCZNIKI NAUK PRAWNYCH

Volume XXVIII, number 3 - 2018

E n g $1 \mathrm{ish}$ ve r s i o

DOI: http://dx.doi.org/10.18290/rnp.2018.28.3-2en

JUDYTA DWORAS-KULIK

\title{
MATERIAL SECURITY FOR MARITIME CLAIMS IN INTERWAR POLAND*
}

\section{PRELIMINARY REMARKS}

After Poland regained independence in 1918, due to the very long period of the Partitions, it did not have its own normative acts that could replace the post-Partition codes. The previous Polish legislation had become obsolete and completely inadequate for the political and legal needs of interwar Poland, therefore, in order to maintain the legal order on its territory, the principle of continuity of law was adopted. The basic normative act regulating issues related to maritime law was Book IV of the German Commercial Code of 10 May 1897 [Handelgesetzbuch, henceforth cited as HGB], Articles 474-905, ${ }^{1}$ adopted in the legislation of the Second Polish Republic by the Act of 1 August 1919 on the government of the Former Prussian Partition. ${ }^{2}$ Other regulations in force at that time in the field of maritime law,

Judyta Dworas-Kulik, PhD, is a research assistant at the Department of History of State and Law, Institute of Law, Faculty of Law, Canon Law and Administration of the John Paul II Catholic University of Lublin; address: Al. Racławickie 14, 20-950 Lublin, Poland; e-mail: dworaskulik@gmail.com; https://orcid.org/ 0000-0002-1990-5497.

* This article is an extended version of J. Dworas-KuliK, "Hipoteka morska w Polsce w okresie międzywojennym," in Badania i Rozwój Młodych Naukowców w Polsce. Nauki humanistyczne i społeczne. Część I, ed. J. Nyćkowiak and J. Leśny (Poznań: Młodzi Naukowcy, 2018), 122-27; IDEM, "Przywilej morski w Polsce w okresie międzywojennym na tle porównawczym," Міжнародні відносини: теоретико-практичні аспекти 2 (2018): 183-93.

${ }^{1}$ See Niemiecki Kodeks handlowy z dnia 10. maja 1897, z uwzględnieniem ustaw uzupetniajacych, ed. T. Zborowski (Poznań: Księgarnia M. Niemierkiewicza, 1912); see also Zbiór ustaw ziem zachodnich, vol. 18, Handlowe i prywatne prawo morskie obowiazujace w Polsce oraz przepisy o polskich statkach handlowych (Poznań: Krajowy Instytut Wydawniczy, 1925).

${ }^{2}$ Dziennik Praw Państwa Polskiego No. 64, item 385. See F. Zoll, "Prawo prywatne międzynarodowe i międzydzielnicowe," reprint from Encyklopedja Podręczna Prawa Prywatnego, nos. 15-16 (Warszawa: Instytut Wydawniczy "Bibljoteka Polska," 1936), 4-53; see also R. Jastrzębski, "Prawo Prywatne międzydzielnicowe. Zarys problematyki," Krakowskie Studia 
relevant for our study, were Articles 1259-1272 of the German Civil Code (hereinafter cited as BGB] $]^{3}$ concerning lien on seagoing vessels. Despite the fact that these regulations were formally in force in the western lands of the Republic of Poland, they were commonly applied because the practical application of lien was determined by the place where agreement were concluded, which in this case were concluded in Gdynia or Gdańsk due their seaside location and the presence of the maritime navigation headquarters. This practice was reflected in the provisions of the inter-provincial legislation. ${ }^{4}$

Work on the unification of the legislation related to maritime law commenced in 1932. ${ }^{5}$ The Sub-Committee on Maritime and River Law was composed of: Stanisław Wróblewski, the chairman, Bronisław Hełczyński, his deputy, Józef Sułkowski, the secretary, and the members Jan Mrozowski and Eugeniusz Waśkowski. The report on the activities of the Codification Commission shows that the preparation of the draft maritime and river law was entrusted to Prof. Sułkowski. ${ }^{6}$ It should be noted that Sułkowski's draft, apart from some provisions in the area of private law, also contained procedural norms and norms of private international law, which regulated some cases of conflict of norms and penal sanctions for violation of the more important provisions. By the outbreak of World War II, the maritime law had not been codified. The purpose of this article is to outline the legal regulations that were in force in interwar Poland concerning liens on things for maritime claims.

\section{MARITIME LIENS IN INTERWAR POLAND ${ }^{7}$}

Maritime liens existing in the two decades of the interwar period were tantamount to preferential claims upon a ship. This term was construed as

z Historii Państwa i Prawa 8, no. 3 (2015): 288. Uniform regulations of international law were developed only on the basis of the Act of 2 August 1926 on the law applicable to private international relations, Journal of Laws No. 101, item 581.

${ }^{3}$ See Niemiecki kodeks cywilny wraz z ustawa wprowadcza, trans. K. Gerschel and H. Damm, vol. 2 (Bydgoszcz: nakładem własnym, 1922); see also B. WinIARsKI, "Hipoteka rzeczna w Polsce," Notarjat i Hipoteka 18, no. 62 (1933): 12-14.

${ }^{4}$ Articles 9, 11-12 of the act of 2 August 1926 r. on the law applicable to private domestic relations.

${ }^{5}$ Act of 3 June 1919 on the Codification Commission, Dziennik Praw Państwa Polskiego No. 44 , item 315 .

${ }^{6}$ See KOMisja KodyfiKacyjna, Sprawozdanie z działalności Komisji Kodyfikacyjnej za czas od 1 czerwca 1932 do 31 maja 1934 (Warszawa: Wydawnictwo Urzędowe Komisji Kodyfikacyjnej, 1934), vol. 1, bk. 16.

${ }^{7}$ For more on maritime lien, see Dworas-Kulik, "Przywilej morski," 183-93. 
rights securing specific claims that were related to the operation of the ship. ${ }^{8}$ Preferential debts were granted the priority in the satisfaction of claims on that ship and other maritime assets, ${ }^{9}$ and therefore they constituted an exception to the principle of equal treatment in relation to all creditors. Preference of certain debts arose by operation of law, without having to register a vessel in the ship register, as was the case with maritime mortgage. ${ }^{10}$ The degree of creditors' preference varied, depending on the status of a particular maritime privilege granted by the legislation. Moreover, the substance of maritime privileges and their hierarchy was conditional, among others, on the nationality of the privileged creditors or the flag of the vessel, as discussed later in this article. These circumstances affected the effectiveness of those privileges and the extent to which the interests of preferential creditors were safeguarded. ${ }^{11}$ The sea privilege expired when the creditor was satisfied. The confidential nature of maritime privileges meant that the privileged creditor might not know that he had special priority over the other debtors. ${ }^{12}$ Maritime privilege as statutory lien was binding despite a change of the creditor or vessel operator-even if the buyer of the vessel acted in good faith.

Provisions concerning maritime privileges on ships can be found in $\S \S$ $754-77$ HGB ${ }^{13}$ They took precedence over all lien claims ( $\$ 776$ HGB). Under $\S 754 \mathrm{HGB}$, which determined the hierarchy of privileges, priority was given to preferential debts arising from the costs related to the guarding and maintenance of a ship as well as its nationality which were not part of the enforcement costs from the time when the ship was brought to the last port in case when the ship was sold by way of execution ( $\$ 754$ subpara. $1 ; \S 766$ HGB). The priority of the next group of preferential debts-where, on the one hand, priority was established on the basis of claims related to the last trip ( $\$ 767$ HGB) and, on the other hand, pursuant to $\S \S 768-69$ HGB, claims relating to the same trip, that is one just commencing or based on a new contract of carriage or one following unloading ( $\$ 757$ HGB)—was derived

\footnotetext{
${ }^{8}$ W. ADAMCZAK, "Pojęcie i charakter prawny przywilejów na statku," Zeszyty Naukowe Wydziatu Prawa i Administracji. Prawo 5 (1977): 49-51.

${ }^{9}$ J. ŁoPUSKI, Encyklopedia podręczna prawa morskiego (Gdańsk: Wydawnictwo Morskie, 1982), 91; see also DwORAS-KuLIK, "Hipoteka morska," 122-27.

${ }^{10}$ DwORAS-Kulik, "Hipoteka morska," 123-24.

${ }^{11}$ ADAMCZAK, "Pojęcie i charakter prawny," 53; see also DwORAS-Kulik, "Hipoteka morska," 124-25.

${ }^{12}$ Leksykon prawa morskiego. 100 podstawowych pojęć, ed. D. Pyć and I. Żużewicz-Wiewiórowska (Warszawa: Wydawnictwo C.H. Beck, 2013): 498-99.

${ }^{13}$ See also W. ADAMCZAK, "Zarys historii przywilejów na statku," Zeszyty Naukowe Wydziatu Prawa i Administracji. Prawo 2 (1974): 13-14.
} 
directly from the order of precedence set out in $\S 754$ HGB, which covered public ship, nautical and port taxes, in particular barrel, light, quarantine and port fees (subpara. 2). Further, § 754 subpara. 3 HGB mentioned debts of the crew of a sea-going ship arising from service and hiring contracts. The privileged creditors were also entitled to a statutory lien on claims arising from previous voyages pursuant to $\S 754$ subpara. 3 insofar as the voyages were based on the same service or hiring contract ( $\$ 758$ HGB). Moreover, such creditors enjoyed an equal right of priority ( $\$ 767 \mathrm{HGB}$ ), since the rights of the creditor were not affected by a situation in which the operator was at the same time liable for the debt at the time when it arose or afterwards ( $\$ 762$ HGB). Further preferential claims were pilots' fees and expenses associated with the provision of shelter, assistance, buyout and complaint-related fees (subpara. 4); next in order were contributions arising from the ship's failure (subpara. 5), claims made by creditors on bottomry who had the title to the ship under lien, and claims arising from any other loan agreements entered into by the captain of a ship in an emergency situation while the ship is out of the home port (see $\S \S 528-41$ HGB), even if the ship's captain was the owner or co-owner of the ship. These claims were treated on a par with the claims resulting from necessary deliveries or emergency services in order to preserve the ship or to make a voyage possible without having to grant credits to the captain, as mentioned above (subpara. 6). We should note here that the claims referred to in $\S 754$ subparas. 4 to 6 of the HGB would be satisfied in the order in which they arose, that is priority was given to debts arising later, but if they were incurred at the same time, the creditors had equal rights by law. Significantly, the various legal acts performed by the captain in connection with the same failure were treated as simultaneous ( $\$ 769 \mathrm{HGB}$ ). Another type of claims were those caused by failure to deliver or by damage to the cargo and hand luggage ( $\$ 769$, subpara. 7 , HGB; see $\S 769$, subpara. 7 HGB; see $\S 673$ subpara. 2 HGB). The provision of $\S 754$ subpara. 8 HGB also referred to the preferential treatment of claims which were not mentioned previously but resulted from legal acts performed by the ship's captain by virtue of his statutory right and not by virtue of a special power of attorney (see $\S 486$ subpara. 1 item 10 HGB). In parallel to the previous claims, there were those arising the ship operator's non-performance, incomplete performance or defective performance of a contract, provided that the performance was one his official duties ( $\S 754$ subpara. $8 \mathrm{HGB}$; see also $\S 486$ subpara. 1 item $2 \mathrm{HGB}$ ). The catalogue of preferential claims also included claims arising from the fault of a crew 
member who was also either the owner or co-owner of the vessel ( $\$ 754$ subpara. 9 HGB; see $\S 485$ and $\S 486$ subpara. 1 point $3 \mathrm{HGB}$ ) and claims against the ship operator arising pursuant to provisions related to accident and disability insurance (para. 10), but the latter claims giving way to all other preferential claims irrespective of the time when they arose ( $\$ 770$ HGB).

The creditors who did not hold a ship as bottomry lien were entitled to a statutory lien on the ship and other maritime assets enforceable against any shipowner ( $\$ 755-56 \mathrm{HGB})$. The creditor was satisfied through claim satisfaction ( $\$ 771 \mathrm{HGB}$ ) or under provisions on forced execution. However, the ship operator was not liable for the satisfaction of creditors against the order of precedence laid down by statute if he was not aware that he was acting to the detriment of priority creditors ( $\$ 772$ HGB). A complaint could be brought against both the ship operator and the ship's captain, even if the ship was at that time in its home port referred to in $\S 480 \mathrm{HGB}$, since the judgement handed down against either of them was also binding on the other ( $\$ 761$ HGB). It did not matter whether the shipowner was an entrepreneur or a company formed under commercial law ( 763 HGB). Moreover, the operator could be held personally liable for the claims if, despite being informed that the ship was encumbered with a preferential claim, he dispatched it on another voyage, even though the creditor's interest did not require this. In such a case, the ship operator was liable up to the amount that would have accrued to the creditor after the sum received was split among the creditors in the statutory order of priority $(\S 774 \mathrm{HBG}){ }^{14}$

A characteristic feature of the provisions of the German Commercial Code was the lack of privilege for the shipyard to secure its claims for failure to pay part of the purchase price of the ship and for payment for the construction and repair of the ship. ${ }^{15}$

\section{BOTTOMRY CONTRACT IN THE POLISH MARITIME LAW OF THE INTERWAR PERIOD}

Another type of security for maritime claims was a bottomry agreement. Bottomry is an archaic form of a maritime loan which developed in the

\footnotetext{
${ }^{14}$ For more on maritime privilege, see DwORAS-Kulik, "Przywilej morski," 183-93.

${ }^{15}$ ADAMCZYK, "Zarys historii," 14; see also W. SowiŃSKI, Prawo handlowe morskie w zarysie (Lviv: Książnica Atlas, 1935), 89-99.
} 
maritime law of northern European countries. It resembled a maritime loan ${ }^{16}$ but was based on the debtor's purely material responsibility. A bottomry loan could also be taken out exclusively for the interest of the cargo during its transport. In such a case, it applied only to the cargo (the so-called respondentia). During the interwar period, the provisions of $\S$ 679-99 HGB were closely related to bottomry.

A bottomry agreement, using statutory powers of attorney, was entered into by the ship's captain outside the home port, for the common interest of the ship and cargo and for a specific voyage. The bottomry involved granting a loan which was secured against a ship. It was usually taken out in in the event of unexpected difficulties during voyage and in the absence of sufficient financial resources to continue it. Most often it was associated with the need to raise money to repair the ship. Hence, during the journey several bottomry loans could be taken out. Bottomry terms and conditions would be spelt out in a letter of bottomry, which in fact was a security stating a unilateral commitment to pay the debt at the port of destination of the voyage on bottomry, that is on the eighth day after reaching that port ( $\$ 687$ HGB). Subsequent creditors had priority in the settlement of the claims specified in letters of bottomry over the previous ones. ${ }^{17}$ Upon landing at the port of destination of the voyage on bottomry, the creditor was allowed to demand a distraint on the goods put in the bottomry lien. The distraint order, pursuant to Section $691 \mathrm{HGB}$, did not require that the reason for it be stated.

The letter of bottomry described the circumstances that forced the captain to enter into the bottomry contract, the date and place of issue of the document, the captain's signature, the surname of the creditor on bottomry, the amount of the bottomry debt expressed in capital, the amount of the premium referred to above or the amount to be paid to the creditor. In addition, the letter contained the designation of the goods in bottomry lien, the name of the ship and its captain, the voyage on bottomry, the time to repay the debt, and the place where the payment was to be made. It was possible to make a letter of bottomry to the order of the creditor or only when ordered by the bottomry provider ( $\S 684 \mathrm{HGB}$ ). When bottomry was furnished, it was possible to require the letter to be issued in several copies, but in such a case it was necessary to indicate on each of them the total number of

\footnotetext{
${ }^{16}$ For more on maritime loan, see G. BLICHARZ, "Pożyczka morska w zachodniej tradycji prawnej," Studia Iuridica Miscellanea 58 (2014): 9-29.

${ }^{17}$ Thanks to the funds raised by the last loan enabled the vessel to reach its destination thus saving the debtor's assets, from which other creditors could also claim satisfaction.
} 
copies issued. The main body of a letter of bottomry was to state explicitly that it was bottomry that was being issued, since under $\S 682 \mathrm{HGB}$ - in the absence of a letter of bottomry, the creditor exercised the same rights as those he would have if the captain had performed an ordinary credit transaction.

Under $\S 680$ HGB, a ship's captain was allowed to conclude a bottomry contract under strictly defined circumstances motivated by necessity and genuine need. A Polish consul or-in his absence-a court or other territorially competent authority or, as the last resort, the officers of the ship in question, confirmed in a document the necessity of taking out such a loan ( $\$ 685$ HGB). The bottomry could be concluded when the ship was outside its home port, in order to complete the voyage or during the voyage, only for the benefit of those having interest in the cargo in order to preserve it and to transport it further to its destination.

The loan could only be reimbursed to the lender once the journey was complete and, as a result, the claim ceased to exist when the pledged assets were lost ( $\$ 690$ HGB). The risk borne by the seller was compensated by a high bottomry premium. ${ }^{18}$ As Section 681 of the German Code states, the amount of the premium was not limited and depended solely on the will of the parties. Moreover, in the absence of a separate contract, it also included interest, which was in principle calculated for the entire bottomry debt, that is also including the premium ( $\$ 687 \mathrm{HGB}$ ). The right to collect the amount borrowed was reserved for the legal holder of a copy of the letter of bottomry. The creditor's satisfaction required that the letter of bottomry be returned, on which the receipt of the amount owed was signed ( $\$ 688$ HGB). In the event when several creditors came forward with other copies of the letter of bottomry, the captain could deposit the amount owed (§689 HGB).

Bottomry was secured by a pledged ship, freight and cargo, and the lender could demand satisfaction from those assets only, namely from the goods secured by bottomry lien ( $\$ 679$ HGB). Satisfaction took place by way of execution for which a final judgement was needed ( $\$ 696$ HGB). In the case of a lien on a ship or cargo, the action had to be brought against the captain or the operator, and a judgement passed on either of them which was enforceable against both. In the case of a pledge on the cargo, however, the complaint had to be brought against the ship's captain. Importantly, the creditor could not exercise his rights to the detriment of the buyer who in

\footnotetext{
${ }^{18}$ The bottomry premium exceeded standard interest, as it usually amounted to $20-30 \%$ of the capital's value.
} 
good faith had obtained the possession of the cargo secured by the bottomry lien. The recipient's knowing about the bottomry debt which encumbered the goods made him liable to the creditor for that debt up to the amount representing the value of the goods at the time of their release, as long as the creditor could claim satisfaction from them, therefore in a situation where they would not be released to the buyer ( $\$ 697$ HGB). However, under $\S 694$ HGB, it was presumed that the creditor could obtain full satisfaction in such situations. In the situation presented above, that is upon the release of the pledged cargo before the creditor was satisfied or the cargo secured, the ship's captain was personally liable to the creditor for the debt on bottomry up to the value of the difference between the debt and the value of the goods released to the buyer. The captain was also personally liable up to the amount of the loan in the event of an arbitrary change of bottomry voyage or arbitrary deviation from the route, as long as that the captain's decision exposed the items secured by the bottomry to a new maritime risk. ${ }^{19}$

The failure to undertake a voyage on bottomry entailed the creditor's right to demand an immediate repayment of the bottomry at the place where the contract was concluded. In such a situation, the premium would be reduced by the ratio of the risk suffered to the risk taken. In the case of premature termination of a voyage on bottomry, that is in a port other than the port of destination, the terms and conditions of the transaction specified in the letter of bottomry, including the date when the debt was to be repaid, remained unchanged ( $\$ 698 \mathrm{HGB})$.

The bottomry loan was replaced by modern types of security for credit, mainly by maritime mortgage and ship arrest. ${ }^{20}$

\section{MARITIME MORTGAGE IN INTERWAR POLAND ${ }^{21}$}

In the theory of maritime law, a merchant vessel flying the flag of a specific state ${ }^{22}$ was an "extension" of its territory, which confirmed its classification as immovable property. The rules governing a contractual lien on

\footnotetext{
${ }^{19}$ The captain was obliged to make sure the goods secured by bottomry were stored and preserved, and therefore it was unacceptable to perform actions augmenting the risk incurred by the creditor or a different risk from that envisaged by the lender in the bottomry agreement. Exposing the lender to greater danger implied the necessity of repairing the damage caused by that situation.

${ }^{20}$ For more on this, see Leksykon prawa morskiego, 38-45.

${ }^{21}$ DwORAS-KuLIK, "Hipoteka morska," 122-27.

${ }^{22}$ See the Act of 28 May 1920 on seagoing commercial vessels, Journal of Laws No. 47, item 285.
} 
a seagoing vessel, despite its mobility, were therefore similar to those governing mortgages on immovable property and hence this kind of pledge was referred to as maritime mortgage. ${ }^{23}$

In Poland, during the interwar period, maritime mortgage was understood as a limited right in rem of an accessory nature, constituting a form of material collateral used in maritime navigation. Maritime mortgage as a special institution of maritime law secured a specific claim entered into the ship register. The entry of maritime mortgage in the register was constitutive in essence, which meant that it created new rights and obligations for the parties to the contractual relationship.

In the post-German legislation in force in western Poland, a distinction was made between contractual liens on registered and unregistered ships. If the vessel was not registered, the lien was governed by the provisions concerning contractual lien on movable property, granting it the status of socalled "pledge-at-hand." Its important feature was the fact that the object of the lien was pledged in the creditor's temporary possession. However, such a lien on merchant seagoing vessels would not be practical or even appropriate, for that matter, as this would put the vessel out of operation and consequently bring a loss of revenue needed to repay the debt. The German legislator created a more effective solution for registered vessels, that is those with a tonnage exceeding $50 \mathrm{~m}^{2}$, which did not limit the debtor's earning capacity - a maritime mortgage operating on the same terms as in the case of a contractual pledge on real estate, i.e. without transferring the possession of the pledged object to the creditor. ${ }^{24}$

To establish a maritime mortgage, a contract was necessary between the ship owner and the creditor represented by the bank granting a loan secured by the vessel (Article 1260 BGB). A maritime mortgage had to be entered in a ship register because, pursuant to Article 1262 BGB, the registration of a lien on a ship in the ship register was valid in the event of disposal, even if the buyer showed good faith, or encumbrance of the ship with another claim. It should be emphasized that no one be excused by ignorance of the entries disclosed in the ship register, since the content of the disclosed or deleted

\footnotetext{
${ }^{23}$ For more on this, see W. SowIŃSKI, "Hipoteka morska z punktu widzenia kodyfikacyjnego," Gazeta Sądowa Warszawska 65, no. 5 (1938): 67-69; compare IDEM, Prawo handlowe; S. MATYSIK, Podręcznik prawa morskiego (Warszawa: Państwowe Wydawnictwo Naukowe, 1967); compare M.H. KoZIŃSKI, "Ewolucja przepisów o hipotece morskiej w prawie polskim," Rejent 107, no. 3 (2000): 30-57.

${ }^{24}$ For more on the ship register: ŁOPUSKI, Encyklopedia, 94; Polskie przepisy morskie, ed. T. Toczyski (Warszawa: Księgarnia F. Hoesicka, 1933), 180-85.
} 
entry was considered to be consistent with the actual state of affairs. The debtor's material liability was limited to the amount entered in the register and the interest on the claim specified therein. However, with respect to statutory interest and costs of the lien, provisions on mortgage on real estate applied. By virtue of $\S 1263$ BGB, a correction of the mortgage entry in the ship register could be requested if there was a formal contradiction in it.

The right of registered lien covered, in accordance with Article 1265 BGB, the nationality of the seagoing vessel, with the exception of goods which were not the property of the shipowner. The liability in this respect was also governed by the provisions on mortgage on real estate. The mortgage creditor was satisfied from the ship on the basis of a enforceable title through a forced sale of the vessel. ${ }^{25}$ Not only a final judgement but also a notarial deed could constitute such a title whereby the shipowner subjected his ship to immediate execution should he fail to meet the deadline for the repayment of the mortgage debt (Article 527 subpara. $5 \mathrm{CCP}$ ).

The Polish legislation, guided by Article 1271 of the German Civil Code, also provided for the possibility of establishing a registered lien on a seagoing vessel analogous to a capped mortgage, whereby only the highest amount up to which the debtor in rem was liable was entered in the ship register. In addition, under $\S 1272$ of the BGB, it was possible to contractually mortgage not only the entire vessel but also its individual shares. In the latter case, the co-owner of the vessel was liable for maritime mortgages up to the value of his share, calculated after deducting his share in the debts of the company formed by the co-owners of the vessel. The enforcement against the entire vessel effected through the sale of the vessel, while the enforcement against a vessel share was achieved by the sale of the share itself.

The formal procedure for registering maritime mortgages was regulated by the act on the non-contentious jurisdiction of May 17, 1898 ( $§ 100-$ 124). The order of the entries was determined by the priority rule set out in Section 1261, Sections 879-81 and Section 1151 of the German Civil Code.

Sea mortgage was extinguished for various reasons, for example when an agreement between the creditor and the debtor redeeming the mortgage was signed, or due to the expiry of the claims for which the mortgage was established, or as a result of subrogation excluding the transfer of the mortgage; also in connection with the merger of the title to the vessel and the mortgage

\footnotetext{
${ }^{25}$ Article 741 and Article 653ff. of the Ordinance of the President of the Republic of Poland of 29 November 1930 - The Code of Civil Procedure, Journal of Laws No. 83, item 651 [henceforth referred to as $\mathrm{CCP}]$.
} 
claim in one person (confusio), in connection with the sale of a ship in the country by way of enforcement, through the sale by the captain outside his home port, which was only possible in a situation of extreme urgency ( $\$ 764$ HGB) or due to the sale of a ship under $\S 25$ of the act on shipwrecked persons, due to sinking or the exclusion of an unknown mortgage creditor by way of public notice procedure ( $\$ 1269$ BGB).

The above-mentioned legal provisions were recognised by the doctrine as the original form of maritime mortgage, since Book IV of the German Commercial Code of 1897 separately regulated the institution of a privileged lien, which was a kind of maritime lien linked to the institution of limited liability of the ship operator, as we mentioned in the preceding section of the article. It should be added that the issue of the statutory security of certain claims on the shipowner's assets was of significant importance to the shipowner, in particular for the assessment of his s creditworthiness, since if the law provided for more burdens on his maritime assets for the benefit of creditors, then the mortgage established on the ship in question was less certain. That had a negative impact on the creditworthiness of the shipowner.

\section{CONCLISION}

Material securities for maritime claims arose by the operation of law or by agreement of the parties, with the ipso iure claims taking precedence over the contractual ones. In the first place, therefore, it was necessary to satisfy the preferential creditors who had maritime liens in the order of their precedence. The contractual security of debts in the form of maritime mortgage gave priority to liens, which at the same time weakened the position of the vessel operator. The entry of maritime mortgage in the ship register guaranteed, however, that the creditor would be satisfied in the order in which it was entered. The above clearly shows that each mortgage creditor had priority to satisfy his claims over bottomry creditors, since the bottomry loan was not entered in the said register. Over the years, this undoubtedly contributed to the abolition of provisions on bottomry and leaving them defunct.

The need to harmonise the rules on maritime claims and to adapt them to the current economic and political situation resulted from the international character of the institutions described above. First of all, the list of maritime liens had to be abbreviated in order to better protect the interests of mortgage creditors, especially since these were public by their entry in the ship 
register. The legal chaos was governed by the International Convention for the Unification of Certain Rules Relating to Maritime Liens and Mortgages of $1926,{ }^{26}$ which was adopted in Polish legislation by the Act of 20 February 1936 on the ratification of the International Convention for the Unification of Certain Rules Relating to Maritime Liens and Mortgages. The ratification law was signed in Brussels on 10 April 1926, but those provisions were not incorporated into the internal legal order. ${ }^{27}$ Thus, the archaic regulations of partition era were in force for the entire interwar period. It should be added that the legislative activity in the area of maritime law in the analysed period was modest, which resulted from the lack of experience and knowledge of international trade in goods and passengers, which would make it possible to create own legal regulations in this matter. Undoubtedly, the delay in the process of maritime law codification was also caused by the organizational and administrative framework which was just being built to deal with matters related to maritime law. We should recall that the work on the maritime and river code began as late as in 1932, despite the fact that the Codification Commission had started its unification of law already in 1919. The work on the unification of maritime law was interrupted by the outbreak of the war, which is why Sulkowski's draft law did not come into force. However, it did not play a significant role in the post-war legislation due to the new socioeconomic situation of the country.

\section{BIBLIOGRAPHY}

SOURCES OF LAW

Konwencja międzynarodowa o ujednoliceniu niektórych zasad, odnoszących się do przywilejów i hipotek morskich, podpisana w Brukseli dnia 10 kwietnia 1926 r. [International Convention for the Unification of Certain Rules Relating to Maritime Liens and Mortgages]. Journal of Laws No. 33, item 260.

Ustawa z dnia 3 czerwca 1919 r. o komisji kodyfikacyjnej [Act of 3 June 1919 on the codification commission]. Dziennik Praw Państwa Polskiego No. 44, item 315.

Ustawa z dnia 1 sierpnia 1919 r. o zarządzie byłej dzielnicy pruskiej [Act of 1 August 1919 on the government of the Former Prussian Partition]. Dziennik Praw Państwa Polskiego No. 64, item 385 .

Ustawa z dnia 28 maja 1920 r. o statkach handlowych morskich [Act of 28 May 1920 on seagoing commercial vessels]. Journal of Laws No. 47, item 285.

\footnotetext{
${ }^{26}$ Journal of Laws No. 33, item 260; for more on this, see W. SowiŃsKI, Konwencje Brukselskie z 1924 r. i 1926 r. dotyczace prawa morskiego (Warszawa: publisher unknown, 1938).

${ }^{27}$ See Leksykon prawa morskiego, 498; compare ADAMCZAK, “Zarys historii,” 14.
} 
Ustawa z dnia 2 sierpnia 1926 r. o prawie właściwem dla stosunków prywatnych międzynarodowych [Act of 2 August 1926 on the law applicable to private international relations]. Journal of Laws No. 101, item 581.

Ustawa z dnia 2 sierpnia 1926 r. o prawie właściwem dla stosunków prywatnych wewnętrznych [Act of 2 August 1926 on the law applicable to private domestic relations]. Journal of Laws of 1926, No. 101, item 580.

Ustawa z dnia 20 lutego 1936 r. w sprawie ratyfikacji międzynarodowej konwencji o ujednoliceniu niektórych zasad, odnoszących się do przywilejów i hipotek morskich, podpisanej w Brukseli dnia 10 kwietnia 1926 r. [Act of 20 February 1936 on the ratification of the International Convention for the Unification of Certain Rules Relating to Maritime Liens and Mortgages]. Journal of Laws No. 15, item 137.

Rozporządzenie Prezydenta Rzeczypospolitej z dnia 29 listopada 1930 r._Kodeks postępowania cywilnego [Ordinance of the President of the Republic of 29 November 1930-Code of Civil Procedure]. Journal of Laws No. 83, item 651.

Komisja KodyfiKacyjna. Sprawozdanie z działalności Komisji Kodyfikacyjnej za czas od 1 czerwca 1932 do 31 maja 1934. Warsaw: Wydawnictwo Urzędowe Komisji Kodyfikacyjnej, 1934, vol. 1 , bk 16 .

\section{LITERATURE}

AdAmCZAK, Wojciech, and Zbigniew Godecki. Przywileje na statku i hipoteka morska. Gdańsk: Wydawnictwo Morskie, 1988.

ADAMCZAK, Wojciech. "Pojęcie i charakter prawny przywilejów na statku." Zeszyty Naukowe Wydziału Prawa i Administracji. Prawo 5 (1977): 49-61.

ADAMCZAK, Wojciech. “Zarys historii przywilejów na statku.” Zeszyty Naukowe Wydziału Prawa i Administracji. Prawo 2 (1974): 7-15.

Blicharz, Grzegorz. "Pożyczka morska w zachodniej tradycji prawnej." Studia Iuridica Miscellanea 58 (2014): 9-29.

Dworas-Kulik, Judyta. "Hipoteka morska w Polsce w okresie międzywojennym.” In Badania i Rozwój Młodych Naukowców w Polsce. Nauki humanistyczne i społeczne. Czesść I, edited by Jędrzej Nyćkowiak and Jacek Leśny, 122-27. Poznań: Młodzi Naukowcy, 2018.

DworAs-Kulik, Judyta. "Przywilej morski w okresie międzywojennym na tle porównawczym." Міжнародні відносини: теоретико-практичні аспекти 2 (2018): 183-93.

JASTRZĘBSKI, Robert. "Prawo Prywatne międzydzielnicowe. Zarys problematyki." Krakowskie Studia z Historii Państwa i Prawa 8, no. 3 (2015): 277-98.

KozıŃSKI, Mirosław H. "Ewolucja przepisów o hipotece morskiej w prawie polskim." Rejent 107, no. 3 (2000): 30-57.

Leksykon prawa morskiego. 100 podstawowych pojęć, edited by Dorota Pyć and Iwona Żużewicz-Wiewiórowska. Warszawa: Wydawnictwo C.H. Beck, 2013.

ŁOPUSKI, Jan. Encyklopedia podręczna prawa morskiego. Gdańsk: Wydawnictwo Morskie, 1982.

MAtysik, Stanisław. Podręcznik prawa morskiego. Warszawa: Państwowe Wydawnictwo Naukowe, 1967.

Niemiecki kodeks cywilny wraz z ustawa wprowadcza, vol. 2. Translated by Karol Gerschel and Henryk Damm. Bydgoszcz: nakładem własnym, 1922. 
Niemiecki kodeks handlowy z dnia 10. maja 1897, z uwzględnieniem ustaw uzupetniających, edited by Tadeusz Zborowski. Poznań: Księgarnia M. Niemierkiewicza, 1912.

Polskie przepisy morskie, edited by Z. Toczyski. Warszawa: Księgarnia F. Hoesicka, 1933.

SowIŃSKI, Władysław. "Hipoteka morska z punktu widzenia kodyfikacyjnego." Gazeta Sadowa Warszawska 65, no. 5 (1938): 67-69.

SowIŃSki, Władysław. Konwencje Brukselskie z 1924 r. i 1926 r. dotyczqce prawa morskiego. Warszawa: publisher unknown, 1938.

SowiŃSKI, Władysław. Prawo handlowe morskie w zarysie. Lviv: Książnica Atlas, 1935.

WiniARSKI, Bohdan. “Hipoteka rzeczna w Polsce.” Notarjat i Hipoteka 18, no. 62 (1933): 12-14.

Zbiór ustaw ziem zachodnich. Vol. 18, Handlowe i prywatne prawo morskie obowiazujace w Polsce oraz przepisy o polskich statkach handlowych. Poznań: Krajowy Instytut Wydawniczy, 1925.

ZoLL, Fryderyk. "Prawo prywatne międzynarodowe i międzydzielnicowe." Reprint from Encyklopedja Podręczna Prawa Prywatnego, nos. 15-16, pp. 4-53. Warszawa: Instytut Wydawniczy "Bibljoteka Polska," 1936.

\section{MATERIAL SECURITY FOR MARITIME CLAIMS IN INTERWAR POLAND}

Summary

The costs related to the construction, purchase, repairs or operation of a sea-going vessel, in particular expenses associated with port fees, fuel, crew and its maintenance during the voyage, were very high and therefore ship owners took out loans secured against their vessel or its cargo to finance the intended operations. Undoubtedly, the development of maritime transport at the turn of $20^{\text {th }}$ century contributed to international unification of maritime law in respect of privileged claims on ships and maritime mortgage. The need for unification of regulations resulted from the necessity to provide creditors with real satisfaction of their claims, because the diversity of local regulations, especially the number of maritime liens created under different legal systems and the hierarchy of their application limited the importance of maritime mortgage. The content of international regulations became the basis for the development of Polish regulations concerning physical collaterals for maritime claims in the era of the Polish People's Republic. It should be added that the maritime law of the interwar period is barely touched on in the available literature on the subject, so this study contributes to the subject of maritime claims.

Key words: maritime mortgage; privileged claim upon a vessel; bottomry; maritime lien; maritime claim; maritime loan.

Translated by Tomasz Pałkowski

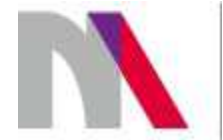

The preparation of the English version of Roczniki Nauk Prawnych (Annals of Iuridical Sciences) and its publication in electronic databases was financed under contract no. 836/PDUN/2018 from the resources of the Minister of Science and Higher Education for the popularization of science. 